\title{
The role of emotional intelligence in attitudes towards elderly patients - Comparative study of medical students from rural and urban areas
}

\author{
Izabela Mamcarz ${ }^{3, A-B, D-F} \oplus$, Kamil Torres ${ }^{3, A, D-F} \oplus$, Piotr Mamcarz ${ }^{2, A, D-F}{ }^{\oplus}$, Krzysztof Jurek $^{1, B-F} \oplus$, \\ Anna Torres ${ }^{4, A, E-F} \oplus$, Konrad Szast ${ }^{3, A-B, E-F} \oplus$ \\ ${ }^{1}$ Faculty of Social Sciences, Institute of Sociology, John Paul II Catholic University, Lublin, Poland \\ ${ }^{2}$ Faculty of Social Sciences, Institute of Psychology, John Paul II Catholic University, Lublin, Poland \\ ${ }^{3}$ Department of Didactics and Medical Simulation, Medical University, Lublin, Poland \\ ${ }^{4}$ Laboratory of Biostructure, Medical University, Lublin, Poland \\ $A$ - Research concept and design, B - Collection and/or assembly of data, C - Data analysis and interpretation, \\ $D$ - Writing the article, $E$ - Critical revision of the article, $F$ - Final approval of article
}

Mamcarz I, Torres K, Mamcarz P, Jurek K, Torres A, Szast K. The role of emotional intelligence in attitudes towards elderly patients -
Comparative study of medical students from rural and urban areas. Ann Agric Environ Med. 2020; 27(1): 134-138. doi: 10.26444/aaem/110770

\section{Abstract}

Introduction. Medical care in geriatrics has its own specificity, and in order to build a successful doctor-patient relationship it is important while studying medicine to learn some functioning aspects of this age group.

Objective. The aim of this study is to explore and describe the role of emotional intelligence in the attitudes of medical students towards elderly patients, taking into account their the place of residence. The place of residence has an impact on social relations and socialization, which could effect with disparities in behaviour towards elderly patients.

Materials and method. Medical University of Lublin students from rural $(N=71 ; M=23.44 \mathrm{SD}=1.80)$ and urban $(N=87$; $M=23.34 ; S D=1.38$ ) areas took part in the study. Emotional Intelligence Questionnaire (INTE) and Attitude Towards Elderly Patients Questionnaire (ATEP) were used.

Results. There are statistically significant differences between medical students from rural and urban areas in their attitude towards elderly patients $(p=0.001)$, but no differences were observed between rural and urban residents in terms of emotional intelligence (general result, action factor and cognitive factor). Positive correlations were observed between action factor $(r=0.322)$, cognitive factor $(r=0.311)$ and general INTE result $(r=0.358)$ and attitude towards elderly patients in the group of medical students from rural area.

Conclusions. Medical students from rural areas are characterized by a more positive attitude towards elderly patients than medical students from urban areas. The predictors of attitudes towards elderly patients are the cognitive factor of emotional intelligence and the place of residence of medical students. The results give the opportunity to design a well-developed programme of a geriatric course which could be matched to the personal predispositions of students.

\section{Key words}

emotional intelligence, geriatrics, medical simulation, place of residence, attitude towards elderly patients

\section{INTRODUCTION}

Nowadays, the aging of the population is an observable phenomenon. The number of older people increases in relation to other age groups [1]. For this reason, special attention has been paid to the education of future health care workers. Researchers describe medical students' attitudes towards the elderly patients and their willingness to work with this group of patients in the future. The results indicate that the majority of respondents have a positive attitude towards geriatric patients, but only 1 in 3 students considers specialization in geriatrics in the future. These patients constitute a large group of people who come to specialists in various domains. In addition to the training of new specialists, the need to improve the knowledge, skills and competences of the physicians already working in the field of geriatric medicine is also emphasized [2].

The functioning of geriatric patients is marked by its

Address for correspondence: Krzysztof Jurek, The John Paul II Catholic University of Lublin, Faculty of Social Sciences, Institute of Sociology, Poland E-mail: kjurek@interia.eu

Received: 18.04.2019; accepted: 05.07.2019; first published: 23.07.2019 specificity. However, the health care workers providing professional medical care do not always have sufficient knowledge in the field of geriatric care [3]. Elderly patients often report ailments of the various body systems which they feel simultaneously and require simultaneous treatment. Communication with such patients is also sometimes difficult or requires more commitment and patience on the part of the physician. Research conducted among nurses also suggests that communication is an important aspect of the offered quality of nursing care. Thus, effective communication could improve the quality of geriatric care $[4,5]$.

Some students exhibit a negative attitude to working with elderly patients $[6,7,8,9]$. This attitude is sometimes due to the fact that these patients are considered by students to be more demanding, often with chronic and incurable diseases [2]. Such an approach can be a prejudice, a generalisation of issues concerning these patients; therefore, it seems important to educate students and prepare them for future work with the elderly, irrespective of the planned specialization [10]. Not only physicians, but also other departments and levels of health care, should be prepared for the changing conditions of the ageing population. Innovative educational strategies 
are being introduced to prepare nurses to work with the elderly, to increase their level of knowledge and shape the attitude which is very important in providing care for these patients [11]. Stereotyping or lack of sufficient knowledge about the functioning of elderly patients translates onto the quality of work and health care by emergency nurses, that are then reflected in the attitude towards the elderly [12]. Researchers point out that there are methods for investigating such a variable as the attitude towards the elderly, but despite the fact that they are accurate and reliable, they are often outdated, adjusted to the conditions of a particular country, and they fail to take into account the patient-centred or the care-centred perspective [13].

The knowledge and attitudes of medical students concerning work with elderly patients may translate into their future career choices, as well as may be directly related to the level and quality of health care for the elderly in the future [14]. The quality of care may influence the development of an appropriate attitude [15]. In this context, it is even more important that medical universities should design and implement classes and courses dedicated to work with this group of patients $[16,17,18,19]$. Insufficient knowledge, prejudices and reluctance are often the cause of negative attitude towards elderly patients.

The research shows both positive and negative attitudes towards the elderly in the majority of physicians undergoing training. Researchers explain this state of affairs as being shaped by many contradictory, heterogeneous factors, such as academic curricula - both formal and less formal - as well as the institutional requirements for physicians to provide effective and efficient health care. Simultaneously with these factors, the aging process is presented in terms of a problem related to the inevitability of physiological aging, as juxtaposed against the capabilities of medical intervention [17]. The literature indicates that the attitude of medical students to elderly patients may also be shaped by personal (and cultural) factors: beliefs, professed values, experience [6, $20]$ and socio-demographic factors: age, gender and socioeconomic status $[16,21,22]$. Studies also confirm that the attitude towards elderly patients exhibited by older students is more positive [10].

Issues related to attitudes towards the elderly are often addressed in research. These activities are guided by the desire to change this attitude or to develop certain competences and skills necessary to provide health care for the elderly $[10,23,24,25]$. Therefore, it seems justified to look for further variables that may influence the development of such attitudes in future physicians. Emotional intelligence might be usefully applied in enhancing the quality of patientcentred care, both directly and indirectly. Ability is a personal characteristic which is regarded as having a potential role in medicine and health care services [26, 27]. It was assumed that attitude towards elderly patients is correlated with emotional intelligence and place of residence. Medical students are the part of health care system, and in the future will in turn provide health services. It is important to know if medical students from different inhibition areas have the knowledge, skills, and competencie, which could be useful for supporting elderly patients. Moreover, different level of emotional intelligence and attitude towards geriatric patients may be observed among medical students from rural and urban areas. Medical students from rural area should be more prepared for understanding the needs of older people because they live more often in multi-generation families. The differences between the aging urban population and the aging rural population naturally create miscellaneous needs, which require professional healthcare services which are aware of these differences [28, 29].

\section{OBJECTIVES}

The aim of the study is to examine whether medical students from rural and urban areas differ in terms of emotional intelligence and attitudes towards elderly patients. Three research hypotheses were put forward: 1) rural students have higher scores on an emotional intelligence scale than urban students; 2) rural students have higher scores regarding attitudes towards elderly patients; 3 ) emotional intelligence correlates with attitudes towards elderly patients.

\section{MATERIALS AND METHOD}

The research group in the presented study were fourthyear students of medicine attending classes in Geriatric Medicine. Selection of the sample was based on two-stage sampling: 1) the students were pre-selected according to place of residence (rural and urban areas) and 2) 100 were selected from each group and were asked to sign the a consent form to complete the questionnaires. After the rejection of incomplete questionnaires, 158 were included in the final statistical calculations. Participation in the study was voluntary and the research project approved by the Bioethics Committee of the Medical University of Lublin. (KE-0254/70/2017).

Two tools were used in the study. The first is the Emotional Intelligence Questionnaire (INTE), developed by Schutte, Malouff, Hall, Haggerty, Cooper, Golden and Dornheim in its Polish adaptation by Jaworowska and Matczak. The tool is based on the initial concept by Salovey and Mayer [30]. The task of the examined person is to determine on a 5-point Likert scale, to what extent the statement refers to him/her. In the Polish version of INTE, apart from the general result, two factors were distinguished, interpreted as the ability to use emotions to support thinking and action (action factor) and the ability to recognize emotions (cognitive factor). The reliability of the INTE questionnaire is satisfactory (Cronbach's alpha values: $0.83-0.87$ ). Absolute stability coefficients are high $(r=0.81$ for women and $r=0.88$ for men) [31]. The other method is the Attitude Towards Elderly Patients Questionnaire developed by Mamcarz (ATEP). At the first stage of the questionnaire design, 57 items are constructed, referring to the attitude of medical students to work with the elderly. At the second stage, the competent judges were asked to evaluate the items. Their task was to evaluate each item on a 5-point Likert scale in terms of how much of its contents corresponded to the purpose of the study. The final version of the questionnaire had 34 items. The tool was evaluated psychometrically. Satisfactory reliability and absolute stability were achieved: Cronbach's alpha $=0.86$; intra-class correlation $=0.811$ (confidence interval of 95\%: $0.736-0.865)$. The attached metric included a question about demographic data (gender, age, place of residence).

Statistical analysis. Statistical analysis was carried out with the IBM SPSS Statistics package (v.25). For qualitative 
variables such as gender and place of residence, the number of categories and their percentage are given. Quantitative variables are described using descriptive statistics: mean and standard deviation. Normality of distributions was confirmed by the W. Shapiro-Wilk test. Two groups were compared with the $t$ test for independent samples. Correlations between analysed variables were checked by Pearson's coefficient. In order to identify predicators of attitudes towards elderly patients, regression analysis was performed (stepwise method). The obtained results of the analysis were assumed to be statistically significant at $\mathrm{p}<0.05$.

\section{RESULTS}

The mean age of respondents was $23.33 \pm 1.58$. There were no significant differences between the rural and urban medical students. The mean age was $23.34 \pm 1.38$ for urban residents and $23.44 \pm 1.80$ for rural residents ( $p>0.05$ ), respectively. Among urban residents, 58.6\% were women and $41.4 \%$ men. In the group of respondents from rural areas there were $63.4 \%$ women and $36.6 \%$ men. The differences in gender distribution in the analysed groups were not statistically significant.

INTE results were similar in both groups of residents. In terms of the activity factor, the average for urban residents was $63.07 \pm 7.40$ and $61.56 \pm 8.10$ for rural residents. In the case of the cognitive factor, the mean values were $43.25 \pm 6.29$ in the urban group and $44.37 \pm 6.39$ in the rural population group. As far as the overall result is concerned, the mean values were as follows: $124.69 \pm 13.79$ for urban residents and $124.34 \pm 14.52$ for rural residents. There were no significant differences between rural and urban residents $(p>0.05)$. The ATEP questionnaire showed that rural residents (110.62 \pm $6.20)$ had a more positive attitude towards older patients than urban residents $(107.18 \pm 6.67)(\mathrm{p}<0.01)$. (Tab. 1$)$.

Table 1. Socio-demographic characteristics, level of emotional intelligence and attitude towards older people, according to place of residence

\begin{tabular}{|c|c|c|c|c|c|c|}
\hline \multirow{2}{*}{$\begin{array}{l}\text { Vari- } \\
\text { ables }\end{array}$} & \multirow{2}{*}{$\begin{array}{l}\text { Cate- } \\
\text { gories }\end{array}$} & \multirow{2}{*}{$\begin{array}{l}\text { Para- } \\
\text { meter }\end{array}$} & \multirow{2}{*}{ Rural [N=71] } & \multirow{2}{*}{ Urban[N=87] } & \multicolumn{2}{|c|}{ SD } \\
\hline & & & & & test & $\mathrm{p}$ \\
\hline Age & Years & $\mathrm{M} \pm \mathrm{SD}$ & $23.44 \pm 1.80$ & $23.34 \pm 1.38$ & $t=-0.771$ & 0.442 \\
\hline \multirow{2}{*}{ Sex } & \multirow{2}{*}{$\begin{array}{c}\text { Woman } \\
\text { Man }\end{array}$} & \multirow{2}{*}{ n (\%) } & $45(63.4)$ & $51(58.6)$ & \multirow{2}{*}{$\chi^{2}=0.199$} & \multirow{2}{*}{0.656} \\
\hline & & & $26(36.6)$ & $36(41.4)$ & & \\
\hline \multirow{3}{*}{ INTE } & $\mathrm{AF}$ & \multirow{3}{*}{$M \pm S D$} & $61.56 \pm 8.10$ & $63.07 \pm 7.40$ & $\mathrm{t}=1.219$ & 0.225 \\
\hline & CF & & $44.37 \pm 6.39$ & $43.25 \pm 6.29$ & $t=-1.099$ & 0.274 \\
\hline & GR & & $124.34 \pm 14.52$ & $124.69 \pm 13.79$ & 0.156 & 0.877 \\
\hline ATEP & GR & $\mathrm{M} \pm \mathrm{SD}$ & $110.62 \pm 6.20$ & $107.18 \pm 6.67$ & $t=3.324$ & 0.001 \\
\hline
\end{tabular}

GR - general result; AF - action factor; CF - cognitive facto

Regarding the action factor, the mean was $64.30 \pm 7.86$ for women and $59.43 \pm 6.56$ for men. The mean cognitive factor was $45.14 \pm 5.89$ for women and $41.59 \pm 6.45$ for men. The overall INTE score for women was $128.55 \pm 14.05$, for men 118.31 \pm 11.75 . Significant differences between women and men were found $(\mathrm{p}<0.05)$. The ATEP was $109.73 \pm 5.99$ for women and $107.18 \pm 7.37$ for men. The difference was statistically significant $(\mathrm{p}<0.05)$ (Tab. 2).

Correlations between cognitive factor and general INTE result and attitude towards older patients proved to be
Table 2. Level of emotional intelligence and attitudes towards the elderly according to gender differentiation

\begin{tabular}{|c|c|c|c|c|c|c|}
\hline \multirow{2}{*}{ Variables } & \multirow{2}{*}{$\begin{array}{l}\text { Cate- } \\
\text { gories }\end{array}$} & \multirow{2}{*}{$\begin{array}{l}\text { Para- } \\
\text { meter }\end{array}$} & \multirow{2}{*}{$\begin{array}{l}\text { Woman } \\
{[\mathrm{N}=96]}\end{array}$} & \multirow{2}{*}{$\begin{array}{c}\text { Man } \\
{[\mathrm{N}=62]}\end{array}$} & \multicolumn{2}{|c|}{ SD } \\
\hline & & & & & test & $\mathrm{p}$ \\
\hline \multirow{3}{*}{ INTE } & $\mathrm{AF}$ & \multirow{3}{*}{$M \pm S D$} & $64.30 \pm 7.86$ & $59.43 \pm 6.56$ & $t=-4.047$ & $<0.001$ \\
\hline & $\mathrm{CF}$ & & $45.14 \pm 5.89$ & $41.59 \pm 6.45$ & $t=-3.562$ & $<0.001$ \\
\hline & $\mathrm{GR}$ & & $128.55 \pm 14.05$ & $118.31 \pm 11.75$ & $t=-4.765$ & $<0.001$ \\
\hline ATEP & GR & $\mathrm{M} \pm \mathrm{SD}$ & $109.73 \pm 5.99$ & $107.18 \pm 7.37$ & $t=-2.282$ & 0.024 \\
\hline
\end{tabular}

$\mathrm{GR}$ - general result; $\mathrm{AF}$ - action factor; CF - cognitive factor

statistically significant in the whole group of respondents. The demonstrated correlations were positive, i.e. a more positive attitude towards elderly patients is accompanied by a higher ability to recognize emotions $(\mathrm{r}=0.251)$ and higher overall emotional intelligence $(r=0.237)$. The attitude towards elderly patients correlated with the action factor, cognitive factor and general INTE result in the group of students from rural area. It turned out that the higher the overall emotional intelligence ( $r=0.358)$, the ability to use emotions to support thinking and action $(\mathrm{r}=0.322)$, and the ability to recognize emotions $(r=0.311)$, the more positive the attitude towards elderly patients. There were no statistically significant dependencies in group of the urban respondents $(\mathrm{p}>0.05)$ (Tab. 3).

Table 3. Correlations between general level of emotional intelligence, action factor and cognitive factor, and attitude towards elderly patients

\begin{tabular}{|c|c|c|c|c|}
\hline & \multicolumn{4}{|c|}{ ATEP } \\
\hline & & Total $[\mathrm{N}=158]$ & Rural [N=71] & Urban [N=87] \\
\hline \multirow{3}{*}{ INTE } & Action Factor & 0.151 & $0.322 *$ & 0.079 \\
\hline & Cognitive Factor & $0.251^{*}$ & $0.311 *$ & 0.172 \\
\hline & General result & $0.237^{*}$ & $0.358^{*}$ & 0.162 \\
\hline
\end{tabular}

In order to identify the predictors of the attitude towards elderly patients, a regression analysis was performed. The proposed model proved to be well suited to the data $(\mathrm{F}(2$, $155)=10.936 ; \mathrm{p}<0.001)$. Place of residence $(\beta=0.260)$ and cognitive factor $(\beta=0.240)$ were significant predictors. A more positive attitude towards elderly patients was associated with living in the countryside and the ability to recognize emotions. The model tested explains $12 \%$ of variability in attitudes towards elderly patients (Tab. 4).

Table 4. Values of regression equation for attitude towards elderly patients, measured by ATEP

\begin{tabular}{lcccc}
\hline Model & B & Beta & $t$ & $\mathrm{p}$ \\
\hline Constant & 93.024 & & 20.717 & $<0.001$ \\
\hline Place of residence & 3.476 & 0.260 & 3.460 & 0.001 \\
\hline Cognitive factor & 0.114 & 0.240 & 3.190 & 0.002 \\
\hline
\end{tabular}

Statistic analysis for the model:

$R^{2}=0.12 ;$ Corrected $R^{2}=0.11 ; F(2,155)=10.936 ; p<0.001$;

Regression equation: $Y=93.024+3.476$

*Place of residence $+0.114 *$ Cognitive factor

a-rural; 0-urban 


\section{DISCUSSION}

As a factorial construct, emotional intelligence enables the description of many internal mechanisms connected with managing emotions, including the ability to use emotions to support thinking and acting (action factor) and the ability to recognize emotions (cognitive factor). The researched medical students from urban and rural areas displayed no statistically significant differences in particular components of emotional intelligence. These studies also did not confirm that the place of residence had a significant impact on the level of emotional intelligence of the students $[32,33,34]$. Taking into account the variable of gender, significant differences existed in all dimensions of emotional intelligence, [35]. This was due to socio-cultural factors shaping emotional development while taking gender into account [36].

The attitude towards the elderly is an important predictor of social relations and can be expressed in both the private and professional areas. This attitude is shaped by many factors, including upbringing, culture, experience and social elements [37]. The results of the study show that there is a significant statistical difference between medical students from rural and urban areas in terms of attitudes towards elderly patients [38]. Medical students living in rural areas show a more positive attitude towards the elderly. In urban areas, there are few multi-generation families. The characteristic of the urban environment introduces natural divisions of particular social groups, which may lead to the alienation of the elderly $[39,40]$. Young people become independent by moving away from a generational family, thus limiting contacts with parents or grandparents. In rural areas, the number of elderly people is higher than in urban areas with reference to the population ratio [40]. Young people living in rural areas have more frequent and intensive interactions and relations with the elderly [41].One symptom of the independence of young rural generations is partitioning of the existing living space or its extension. The consequence of this may be that several generations will coexist in one building. The literature indicates that in rural areas a greater culture of family care for elderly people can be observed than in urban areas [42]. This may result from the lack or limited access to assistance centres (retirement homes, universities of the third century, health service), which makes it natural for family members to take care of the elderly [43].

The results of own research show that men and women do not differ significantly in their attitudes towards elderly patients. This is an interesting result, because assuming the cultural characteristics of the subjects and gender contrasts in terms of interpersonal competences, social roles, emotional intelligence and other variables shaping attitudes, the lack of dependence is not obvious [35, 44].

On the basis of the conducted research, it can also be concluded that emotional intelligence is an important factor determining the attitude towards elderly patients. The model of relationships with the elderly patient should take into account the influence of the ability of medical personnel to perceive, regulate and manage emotions [45].

Summarizing the results, the place of residence and the ability to recognize emotions are predictors of attitudes towards elderly patients. Thanks to these results, it is possible to understand mechanisms determining attitudes towards elderly patients, and thus try to introduce tools to correct differences between groups in the medical education process. This field of research is important because it affects the healthcare system. The positive student's attitude towards elderly patients can change the accessibility and quality of healthcare in the future. Professional trainings and clinical courses should be designed to develop essential attitudes and level out the emotional intelligence of future professionals.

A limitation of this study was the relatively small sample. It is important to note that the research was carried out only among medical students who were in the fourth year of study. Moreover, the implementation of research on attitudes towards elderly patients during geriatric medicine classes can significantly affect the declared attitudes.

This research was a pilot study, the main aim of which was to identify the relationship between the emotional intelligence of medical students from rural and urban areas and attitudes towards elderly patients.

\section{CONCLUSIONS}

1. No differences were found between medical students from rural and urban areas in terms of emotional intelligence (general result; action factor; cognitive factor).

2. Medical students from rural areas were characterized by a more positive attitude towards elderly patients than medical students from urban areas.

3. The level of emotional intelligence of medical students, regardless of place of residence, influenced the positive attitude towards elderly patients.

4. The predictors of attitudes towards elderly patients were the cognitive factor of emotional intelligence and the place of residence of medical students.

\section{Conflicts of Interest}

The authors declare that there is no conflict of interest in the authorship and publication of the study. The authors received no sponsored sources of finance for the conducted research.

\section{REFERENCES}

1. Abramowska-Kmon A. O nowych miarach zaawansowania procesu starzenia sięludności (On newmeasures of the populationageingprocess). DemographicStudies 2011; 1(159): 3-22.

2. Chua MP, Tan Ch, Merchant R, Soiza RL. Attitudes of first-year medical students in Singapore towards older people and willingness to consider career in geriatric medicine. Ann Acad Med Singapore. 2008; 37: 947-51.

3. Higgins I, Der Riet, PV, Slater L, Peek C. The negative attitudes of nurses towards older patients in the acute hospital setting: A qualitative descriptive study. Contemp Nurse. 2007; 26(2): 225-237.doi:10.5172/ conu.2007.26.2.225

4. Caris-Verhallen WM, de Gruijter IM, Kerkstra A, Bensing JM. Factors related to nurse communication with elderly people. J Adv Nurs. 2001; 30(5): 1106-1117.

5. Omid A, Haghani F, Adibi P. Emotional Intelligence: An Old Issue and a New Look in Clinical Teaching. Adv Biomed Res. 2018; 7: 32. doi: $10.4103 / 2277-9175.225926$

6. Lovell M. Caring for the elderly: Changing perceptions and attitudes. J VascNurs. 2006; 24(1): 22-26. doi:10.1016/j.jvn.2005.11.001

7. Kishimoto M, Nagoshi M, Williams S, Masaki KH, Blanchette PL. Knowledge and attitudes about geriatrics of medical students, internalmedicine residents and geriatric medicine fellows. J Am Geriatr Soc. 2005; 53: 99-102.

8. Adelman RD, Fields SD, Jutagir R. Geriatric education. Part II: the effect of a well elderly program on medical student attitudes toward geriatric patients. J Am Geriatr Soc. 1992; 40: 970-3. 
9. Wilkinson TJ, Gower S, Sainsbury R. The earlier, the better: the effect of early community contact on the attitudes of medical students to older people. Med Educ. 2002; 36: 540-2.

10. Hughes NJ, Soiza RL, Chua M, Hoyle GE, Macdonald A, Primrose WR, Gwyn Seymour D. Medical Student Attitudes Toward Older People and Willingness to Consider a Career in Geriatric Medicine. J Am Geriatr Soc. 2008; 56(2):334-338. doi:10.1111/j.1532-5415.2007.01552.x

11. Burbank P, Dowling-Castronovo A, Crowther. MR, Capezuti EA. Improving Knowledge and Attitudes Toward Older Adults Through Innovative Educational Strategies. J ProfNurs. 2006; 22(2): 91-97. doi:10.1016/j.profnurs.2006.01.007

12. Hanson RM. "Is elderly care affected by nurse attitudes?" A systematic review. Br J Nurs. 2014; 23(4): 225-229. doi:10.12968/bjon.2014.23.4.225

13. Courtney MD, Tong SS, Walsh AK. Acute-care nurses' attitudes towards older patients: a literature review. Int J Nurs Pract. 2000; 6(2): 62-69.

14. Gething L, Fethney J, McKee K, Goff M, Churchward M, Matthews S. Knowledge, stereotyping and attitudes towards self ageing. AJA. 2002; 5: 165-168.

15. Schwartz LK, Joseph Simmons P. Contact quality and attitudes toward the elderly. EducGerontol. 2001; 27(2): 127-137. doi:10.1080/03601270151075525

16. Cankurtaran M, Halil M, Ulger Z, Dagli N, Yavuz BB, Karaca B, Ariogul S. Influence of medical education on students' attitudes towards the elderly. J Natl Med Assoc. 2006; 98(9): 1518-22.

17. Higashi RT, Tillack AA, Steinman M, Harper M, Johnston CB. Elder care as "frustrating" and "boring": Understanding the persistence of negative attitudes toward older patients among physicians-in-training. J Aging Stud. 2012; 26(4): 476-483. doi:10.1016/j.jaging.2012.06.007

18. Varkey P, Chutka DS, Lesnick TG. The Aging Game: improving medical students' attitudes toward caring for the elderly. J Am Med DirAssoc. 2006; 7(4): 224-9.

19. Westmoreland GR, Counsell SR, Sennour Y, Schubert CC, Frank KI, Wu J, Frankel RM, Litzelman DK, Bogdewic SP, Inui TS. Improving Medical Student Attitudes Toward Older Patients Through a Council of Eldersand Reflective Writing Experience. J Am Geriatr Soc. 2009; 57(2): 315-320. doi:10.1111/j.1532-5415.2008.02102.x

20. Taylor LF, Tovin MM. Student Physical Therapists' Attitudes Toward Working with Elderly Patients. Phys Occup Ther Geriatr. 2006; 18(2): 21-37. doi:10.1080/j148v18n02 02

21. Austin EJ, Evans P, Goldwater R, Potter V. A preliminary study of emotional intelligence, empathy and exam performance in first year medical students. Pers IndivDiffer. 2005; 39(8): 1395-1405.

22. Hweidi IM, Al-Obeisat SM. Jordanian nursing students' attitudes toward the elderly. Nurse Educ Today. 2006; 26(1): 23-30. doi:10.1016/j. nedt.2005.06.003

23. Hamrick I, Weiss G, Lippert H, Meyer F. Geriatric problems in the perioperative management of surgical interventions. Zentralbl Chir. 2005; 130: 41-47.

24. Nobili A, Garattini S, Mannucci PM. Multiple diseases and polypharmacy in the elderly: challenges for the internist of the third millennium. J Comorbid. 2011; 1: 28-44.

25. Boyd CM, Darer J, Boult C, Fried LP, Boult L, Wu AW. Clinical practice guidelines and quality of care for older patients with multiple comorbid diseases: implications for pay for performance. JAMA 2005; 294 : 716 724.

26. Lewis GM, Neville C, Ashkanasy NM. Emotional intelligence and affective events in nurse education: A narrative review, Nurse Educ Today. 2017; 53(1): 34-40. doi: 10.1016/j.nedt.2017.04.001

27. Nightingale S, Spiby H, Sheen K, Slade P. The impact of emotiona intelligence in health care professionals on caring behaviour towards patients in clinical and long-term care settings: Findings from an integrative review. Int J Nurs Stud. 2018; 80: 106-117. doi: 10.1016/j. ijnurstu.2018.01.006
28. Karamivand V, Bastani F, Haghani H. Supportive needs of urban and rural elders. J Aging Geriatr Psychiatry. 2018; 2(2): 1-6.

29. Ćwirlej-Sozańska AB, Sozański B, Wiśniowska-Szurlej A, WilmowskaPietruszyńska A. Quality of life and related factors among older people living in rural areas in south-eastern Poland. Annals of Agricultural and Environmental Medicine. 2018; 25(3): 539-545. doi:10.26444/ aaem/93847

30. Salovey P, Mayer JD. Emotional intelligence. Imagin. Cogn. Pers. 1990; 8: $185-211$.

31. Jaworowska A, Matczak A. Kwestionariusz Inteligencji Emocjonalnej INTE N. S. Schutte, JM. Malouffa, LE. Hall, DJ. Haggerty'ego, JT. Cooper, CJ. Goldena, L. Dornheim (INTE emotionalintelligencequestionnaire by NS. Schutte, JM. Malouff, LE. Hall, DJ. Haggerty, JT. Cooper, CJ. Golden, L. Dornheim). Pracownia Testów Psychologicznych Polskiego Towarzystwa Psychologicznego. Warszawa 2001.

32. Tyszkiewicz-Bandur M. Poziom inteligencji emocjonalnej a typ przywiązania u studentów III roku Wydziału Nauk o Zdrowiu oraz Wydziału Lekarskiego - analiza porównawcza (Levels of emotional intelligence and types of attachment among third year students of the Faculty of Health Science and the Faculty of Medicine - a comparative analysis). Ann Acad Med Stetin. 2013, 59(2): 109-117.

33. Sundararajan S, Gopichandran V. Emotional intelligence among medical students: A mixed methods study from Chennai, India. BMC Med Educ. 2018; 18: 97. doi: 10.1186/s12909-018-1213-3

34. Datta J, Chetia P, Soni JC. Academic Achievement, Emotional Maturity, and Intelligence of Secondary School Students in Assam. Int J Sci Res. 2016; 5(7): 1159-1171.

35. Todres M, Tsimtsiou Z, Stephenson A, Jones R. The emotional intelligence of medical students: An exploratory cross-sectional study. Med Teach. 2010; 32(1): 42-48. doi: 10.3109/01421590903199668

36. Fernández-Berrocal P, Cabello R, Castillo R, Extremera N. Gender differences in emotional intelligence: The mediating effect of age. Behav Psychol PsicolConduct. 2012; 20(1): 77-89.

37. North MS, Fiske ST. Modern attitudes toward older adults in the aging world: A cross-cultural meta-analysis. Psychol Bull. 2015; (5): 993-1021. doi:10.1037/a0039469

38. Samra R, Cox T, Gordon AL, Conroy SP, Lucassen MFG, Griffiths A. Factors related to medical students' and doctors' attitudes towards older patients: A systematic review. Age Ageing. 2017; 46(6): 911-919. doi:10.1093/ageing/afx058

39. Phillipson C, Scharf T. Rural and urban perspectives on growing old: Developing a new research agenda. Eur J Ageing. 2005; 2(2): 67-75. doi: 10.1007/s10433-005-0024-7

40. Central Statistical Office. Population. Size and Structure and Vital Statistics in Poland by Territorial Division in 2016.

41. Guo M, Chi I, Silverstein M. The Structure of Intergenerational Relations in Rural China: A Latent Class Analysis. J Marriage Fam. 2012; 74: 1114-1128. doi:10.1111/j.1741-3737.2012.01014.x

42. Silverstein M, Cong Z, Li S. Intergenerational transfers and living arrangements of older people in rural China: Consequences for psychological well-being. J Gerontol B Psychol Sci Soc Sci. 2006; 61(5): 256-266.

43. Averill JB. Priorities for action in a rural older adults study. Fam Community Heal. 2012; 35(4): 358-372. doi: 10.1097/ FCH.0b013e318266686e

44. Randler C, Vollmer C, Wilhelm D, Flessner M, Hummel E. Attitudes Towards the Elderly Among German Adolescents. EducGerontol. 2014; 40(3): 230-238. doi:10.1080/03601277.2013.802187

45. Arora S, Ashrafian H, Davis, Athanasiou T, Darzi A, Sevdalis N. Emotional intelligence in medicine: a systematic review through the context of the ACGME competencies. Med Educ. 2010; 44: 749-764. doi:10.1111/j.1365-2923.2010.03709.x

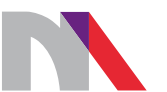

Ministry of Science and Higher Education

Republic of Poland

Generation of the DOI (Digital Object Identifier) - task financed under the agreement No. 618/P-DUN/2019 by the Minister of Science and Higher Education 